\title{
STUDY OF THE USE OF THE THREE LEVELS OF THINKING AND REPRESENTATION
}

\author{
Marina Stojanovska $^{1^{*}}$, Vladimir M. Petruševski $^{1}$, Bojan Šoptrajanov $^{2}$ \\ ${ }^{1}$ Institute of Chemistry, Faculty of Natural Sciences and Mathematics, \\ Ss. Cyril and Methodius University, Skopje, Republic of Macedonia \\ ${ }^{2}$ Macedonian Academy of Sciences and Arts, Skopje, Republic of Macedonia \\ *Corresponding author, e-mail: marinam@pmf.ukim.mk
}

\begin{abstract}
As is well-known, the chemical knowledge is acquired at three levels: the macroscopic and tangible (what can be seen, touched and/or smelt); the sub-microscopic (atoms, molecules, ions and structures) and the representational (symbols, formulae, equations, mathematical manipulation, graphs etc.).

In order to acquire real knowledge, all factors involved in the educational process (authors of textbooks, teachers, electronic sources of information and students) should do everything possible to avoid formation of school-made erroneous notions (misconceptions).

Reported here are the findings of a study on the presence of students' misconceptions regarding the three levels of representation in the chemistry teaching in the Republic of Macedonia. As our study showed, many school-made misconceptions are due to the fact that students do not distinguish between the three levels of thinking/representation.
\end{abstract}

Key words: the three levels of thinking/representation; chemistry teaching; misconceptions; interviews

\section{INTRODUCTION}

There are many terms that refer to students' misbelieves. Some authors use the word preconceptions or preconcepts to emphasize the importance of children's ideas developed before and during their early school years; others use misconceptions, misunderstandings, misinterpretations of facts, naive believes etc. The expression alternative conceptions is considered by some authors as some kind of compromise that incorporates students' faulty views during science teaching [1]. Still, in the literature on chemistry education, the prevalent word describing the erroneous notions is the word misconceptions. The term "misconception" could be defined as "an idea which is wrong because it has been based on a failure to understand a situation" [2] although alternative definitions could also be given.

The misconceptions are powerful, extremely persistent and highly resistant to change or alteration, creating obstacles to further learning $[3,4]$.
The erroneous notions can be formed before the schooling or in its early stages (sometimes, these are called preconcepts) but could also originate from the content of textbooks, as well as from teachers (their knowledge and attitude). Thus, although the teaching process generally leads to acquiring and understanding various concepts, in some cases it may misguide students and lead to the formation of misconceptions.

Needless to say, chemistry is a subject which, necessarily, is based on concepts, many of which are abstract and are therefore hard to grasp and learn, especially when the students are put in a position to believe without seeing. This is most certainly a basis for occurrence of new or strengthening of already existing misconceptions.

Misconceptions can be derived from the textbook illustrations and used animations $[5,6]$, textbooks of other subjects, the inconsequent chapter organization [7], the teachers $[8,9]$ or the way of teaching. Misconceptions that originate from the 
teaching process are known as school-made misconceptions [10].

According to Johnstone [11], the chemical knowledge is acquired at three levels: a) the macroscopic and tangible (what can be seen, touched and/or smelt); b) the sub-microscopic (atoms, molecules, ions and structures) and c) the representational (symbols, formulae, equations, mathematical manipulation, graphs, etc.) and this is now considered to be a truism. None of the above-mentioned aspects is superior to another; on the contrary, they rather complement each other.

Some of the reasons for occurrence of misconceptions in chemistry could be traced to problems of the specific terminology and used wording, especially when introducing the concepts of substances, the particles of which they consist and chemical symbols used for their representation (macroscopic, sub-microscopic and symbolic respectively).

Many school-made misconceptions are due to the fact that students do not distinguish between macroscopic and sub-microscopic explanations [12-16]. There are, at least, two possible reasons for the emerging of misconceptions when dealing with the three mentioned levels of representation. The first is the risk of "overloading the working memory space" [17] when students are introduced to all three levels simultaneously. Secondly, neglecting the sub-microscopic level during teaching may also lead to the appearance of certain misconceptions. Seemingly, it would be better that chemistry concepts are taught progressively: starting with macroscopic observation, through the sub-microscopic interpretations and only then work with the symbolic representations.

Many basic chemistry concepts are difficult to teach because "the definitions of these concepts given in textbooks either lack precision, or invoke ideas that beginners are not familiar with, and have to accept on trust" [18]. Conceptual knowledge about chemical reactions (a subject present in any chemistry textbook) implies awareness of the three levels of representation. Students have to be able to go from the macroscopic level (observations, experiments) to the sub-microscopic level in order to understand the changes that happen during chemical reactions and then learn to present the acquired knowledge in a symbolic way. Unfortunately, chemical reactions are being taught, most of the time, only through chemical equations, thus stimulating only the low-level knowledge (memorizing and/or recognizing) $[19,20]$.

In the last few decades many misconceptions concerning various chemistry (and science in general) topics have been documented $[1,21]$ and many science misconceptions and difficulties in learning and understanding chemical concepts have been reported [22-29]. The misconceptions regarding the three levels of representation are closely related not only to the false ideas about the chemical reactions [30-32], but also to the ideas involving the particulate nature of matter [15, 33-43], the law of conservation of matter $[44,45]$, the physical and chemical changes $[18,30,31,46,47]$, the solutions [24, 48] etc.

Particle theory concepts are an integral part of the eighth-grade (secondary-school) curriculum in the Republic of Macedonia. At the very beginning of learning chemistry as a subject, students encounter the bulk properties (physical and chemical) of substances and then their structure. Chemical symbols, formulae and equations come later. Nonetheless, as will be shown, the results of our investigation showed that many students have not developed an accurate understanding of these concepts and the consistency in reasoning among students of different levels of study confirmed the fact that they retained their misconceptions over the years.

Sadly, this is not the case only of our students but vagueness is present even in the presentations of the periodic table of elements. If one looks closely, it can be noticed that some data refer to the atoms of the elements (e.g. electronic configuration) and other are related to the elementary substances that are composed of these particles (e.g. density) [49]. All three levels of representation are present and mixed (obviously, in an unfortunate manner) in the published form of the periodic table, so it undoubtedly brings some confusion among students.

The interference of macroscopic (colour, density, melting point or solubility) and submicroscopic concepts (size and mass of the particles) by students may be due to the lack of ability to adequately describe the learned concepts [10] but is, even more likely, a result of a confusion of ideas. Thus, in many cases, the ideas of students that when a gas is being compressed (macroscopic representation), the particles (sub-microscopic representation) are not only pushed closer together but also compressed themselves are present [16]. Further examples are given by Barke et al. [10] who quote some students' statements, such as: "sulfur particles are yellow", "sugar particles are sweet", "water is a fluid and consists of liquid particles", "ice particles are solid", "carbon particles burn and turn to ash" etc.

Misconceptions originating from interference between the three levels of representation in the chemistry teaching process are present not only 
among students, but also among teachers, educators and researchers and even among respected authors of scholarly papers, as well as authors of textbooks. Thus, in many textbooks statements can be found in which a substance reacts with one or more particles (atoms, molecules, ions ...), such as: "This ion reacts with the glucose, oxidizing it to form an acid and the ion itself reduces to elementary silver" [50]. Similar (basically incorrect) notions are present in statements such as: "When forming ionic compounds, iron gives off three electrons." [51], "The elementary substance phosphorus consists of four atoms of element phosphorus." [51], "Acid molecules comprised of one hydrogen atom are called monoprotic acids." [52] etc.

In view of such an unfortunate state of affairs, it is clear that an in-depth understanding of concepts is needed rather than just memorizing facts and rote learning. One of the possible solutions to ameliorate the situation is to have teachers and educators focused on the implementation of instructional programs aimed to help students in overcoming erroneous concepts they have. Another, perhaps simpler, solution is to educate the educators to notice such false statements and correct them during their class work.

In the present paper we report the findings from an experimental study of students' misconceptions regarding the three levels of representation. The investigation was intended to check the capability of students of different educational levels (samples of students from secondary- and highschools were tested) to transfer their knowledge through the three levels of representation. Given is a list of misconceptions detected among students, as well as excerpts from interviews to give evidence for the students' reasoning. We believe that the results of this research will find their place in the chemistry teaching in the Republic of Macedonia, and, hopefully, will ameliorate it.

\section{EXPERIMENTAL SECTION}

In this study, as is the case in many educational investigations, a combination of quantitative and qualitative data collection techniques was used and two kinds of instruments were implemented: multiple-choice concept tests and interviews (semistructured individual interviews and focus groups), such a combination being known as triangulation $[53,54]$. Interviews, both individual $[55,56]$ and in a group [57-60], have been successfully used as data collection instruments in educational studies when looking for in-depth explanations. Details about the instruments and the procedures are given elsewhere [32, 43]. Additionally, a pilot study, testing the possible misconceptions regarding the law of conservation of matter has been performed $[61,62]$.

The percentage of correct answers to the test items as well as that of wrong ones was estimated. The high value of the latter could indicate presence of students' misconceptions on the tested concepts [19]. Namely, as a somewhat rough rule of thumb, a statement represented as a distractor can be considered to be a misconception if it is chosen by more than $20 \%$ of the students.

The interview transcripts were used to locate gaps in knowledge and segments that can be regarded as misconceptions. Interview discussions were also used either to confirm the misconceptions found by the analysis of the tests or to indicate the existence of new ones. All interviews were conducted in Macedonian (the excerpts quoted in this paper were translated into English). The excerpts from the interview transcripts that are presented in the paper could enable the readers to examine the trustworthiness of the research procedure.

\section{RESULTS AND DISCUSSION}

The summary of the findings from the testing and interviewing students is given in this section, with a stress on the misconceptions found among students in the test and through interview discussions. Namely, during the testing, some distractors were favoured for certain items and thus 21 misconceptions were identified in the answers given by students. Several more misconceptions emerged on analyzing the interview transcripts. The misconceptions found in the written responses are listed in Table 1 . The percentages of students holding particular misconceptions were also calculated and are summarized in the same table.

Other misconceptions were detected in the test answers of certain sub-samples. Thus, among eighth-grade students, a notion that "particles receive heat and enlarge" (M22) was rather common (33\% of students have chosen this option in the test). Three more misconceptions were revealed in the second-year high-school sub-sample analysis. The statements commonly present among such students were that: a) "carbon, hydrogen and oxygen atoms (of which ethanol is composed) will disappear when ethanol is ignited" (32\%; M23), b) "particles of a substance are shrinking during heating of that substance" (28\%; M24) and c) "NaCl entities in aqueous solution can be present both as molecules and ions" (30\%; M25). 
Table 1. Misconceptions (M) found among students during testing

\begin{tabular}{|c|c|c|}
\hline \multicolumn{2}{|c|}{ Misconception } & \multirow{2}{*}{$\frac{\text { Percent }}{27}$} \\
\hline M1 & Butadiene reacts with two bromines & \\
\hline M2 & Butadiene reacts with one molecule of bromine & 61 \\
\hline M3 & $\begin{array}{l}\text { Copper(II) sulfate from aqueous solution crystallizes as a solid substance composed } \\
\text { of copper(II) sulfate molecules [fail to distinguish ionic from covalent substances, so } \\
\text { they refer to all building particles as molecules] }\end{array}$ & 35 \\
\hline M4 & Particles change from solid to liquid ones & 50 \\
\hline M5 & $\begin{array}{l}\text { When ethanol is ignited, carbon, hydrogen and oxygen atoms (of which ethanol is } \\
\text { composed), will ignite too and will burn just like the ethanol }\end{array}$ & 26 \\
\hline M6 & The particles of a substance enlarge during heating that substance & 50 \\
\hline M7 & $\begin{array}{l}\mathrm{NaCl} \text { entities in aqueous solution react with the water and sodium and chlorine are } \\
\text { formed }\end{array}$ & 34 \\
\hline M8 & Instead of $3 \mathrm{~N}_{2}$, in a chemical equation, one can write $6 \mathrm{~N}$ & 23 \\
\hline M9 & Gas (water vapor) weighs less than liqiud [matter is not conserved in evaporation] & 41 \\
\hline M10 & $\begin{array}{l}\text { A sealed container with a bit of acetone in it weights less after the liquid (acetone) } \\
\text { has evaporated }\end{array}$ & 30 \\
\hline M11 & Weight (mass) is lost in dissolving & 61 \\
\hline M12 & Solute (eg. salt) disappears when dissolved & 47 \\
\hline M13 & Precipitation reaction results in increasing the mass & 34 \\
\hline M14 & Mass increases in precipitation because solid weights more than the liquid & 21 \\
\hline M15 & A rusting nail won't change weight & 38 \\
\hline M16 & The iron had only reacted with the oxigen in the air which does not weigh anything & 27 \\
\hline M17 & The rust eats up the metal & 25 \\
\hline M18 & Exhaust gasses from burning petrol weight less than the petrol $\ldots$ & 36 \\
\hline M19 & $\ldots$ because gas is lighter & 31 \\
\hline M20 & Mass is lost in combustion & 36 \\
\hline M21 & Combustion is a change of state of matter & 32 \\
\hline
\end{tabular}

In Table 2, excerpts from the conversations between the researcher (R) and student/s (S) are given to illustrate and support the finding regarding students' misconceptions. After every excerpt a brief description is given that includes the type of school (SS or HS for secondary- and high-school respectively), the level of education within the school in question (given by Roman numerals) and the sub-group to which the student belongs (high achievers are students having grade 4 or 5 and low achievers are classified those that have grade 2 or 3 according to their previous school achievements) ${ }^{1}$.

The most common misconceptions of students identified during the interviews were those that reflected ideas about the size and shape of molecules when the substance undergoes a phase change. Some students believed that the particle size must be changed and they explained that the expansion of matter is due to the expansion of particles rather than to increased particle spacing (for example, molecules allegedly can stretch and expand when a substance is heated); others thought that the particles of a given substance in different states (solid, liquid and gaseous) have different properties (for example, the molecules of liquid/gaseous water are softer and weigh less than the molecules of ice/liquid water).

1 In the Macedonian system of grading, five integers (from 1 through 5) are used: 5 (excellent) is the highest and 1 (fail) is the lowest grade. 
Table 2. Excerpts from the interview transcripts for corresponding misconceptions

\begin{tabular}{|c|c|}
\hline $\begin{array}{l}\text { Miscon- } \\
\text { ception }\end{array}$ & Excerpt \\
\hline M1 & $\begin{array}{l}\text { I have calculated correctly: there are two atoms of bromine and that is why butadiene reacts with two } \\
\text { atoms of bromine. (SS-VIII-high achievers) }\end{array}$ \\
\hline M2 & $\begin{array}{l}\text { I considered that } \mathrm{Br}_{2} \text { is one molecule of bromine, so my answer is that butadiene reacts with one } \\
\text { molecule of bromine. (HS-II-low achievers) }\end{array}$ \\
\hline M3 & $\begin{array}{l}\text { R: Do you think that molecules of copper(II) sulfate exist? } \\
\text { S10: Yes. } \\
\text { R: Could you explain in more detail what do you mean? } \\
\text { S10: I don't know ... I'm not sure. } \\
\text { S9: I think that molecules of copper(II) sulfate do not exist because copper(II) sulfate is a compound. } \\
\text { R: What about water? Is water a compound? } \\
\text { S9: Well ... yes. } \\
\text { R: Does it consist of molecules? } \\
\text { S9: Yes, it does. } \\
\text { R: When is it right to say "molecules"? } \\
\text { S12: When we talk about ions, it must be an ionic bonded compound. } \\
\text { (HS-II-high achievers) }\end{array}$ \\
\hline M4 & $\begin{array}{l}\text { My answer is that particles change from solid to liquid ones. For example, if we put ice cubes in a } \\
\text { drink, after same time they will melt and turn to liquid state. According to this, I thought that this } \\
\text { answer is the most appropriate. (SS-VIII-high achievers) }\end{array}$ \\
\hline M5 & $\begin{array}{l}\text { R: Why do you think that atoms will burn? } \\
\text { S: Well, because ethanol has oxygen in its structure and it is able to burn. (SS-VIII-high achievers) }\end{array}$ \\
\hline M6 & $\begin{array}{l}\text { When heating an object, particles become wider. (HS-IV-high achievers) } \\
\text { When heat gets inside the particles, they are heated and, due to that, increase their size. (SS-VIII-low } \\
\text { achievers) }\end{array}$ \\
\hline M7 & $\begin{array}{l}\text { S: Well, the whole } \ldots \mathrm{NaCl} \ldots \text { can exist as a molecule, but if we are talking about its entities - they } \\
\text { can not. } \\
\text { R: What are its entities? } \\
\text { S: Sodium and chlorine. (HS-III-high achievers) }\end{array}$ \\
\hline M8 & $\begin{array}{l}\text { R: Your test answer is "6N"? What does the number } 2 \text { means [pointing to } 3 \mathrm{~N}_{2} \text { ]? } \\
\text { S: Nitrogen is non-metal and that's why we must write } 2 \text {. If we multiply that with three molecules } \\
\text { we get six atoms, which is the same representation as } 6 \mathrm{~N} \text {. (HS-I-high achievers) }\end{array}$ \\
\hline M9 & I \\
\hline M10 & $\begin{array}{l}\text { R: Why did you answer that the mass of the container will be smaller than the initial one? } \\
\text { S: Well ... the substance binds to the oxygen. (HS-I-high achievers) }\end{array}$ \\
\hline $\begin{array}{l}\text { M11 } \\
\text { and } \\
\text { M12 }\end{array}$ & $\begin{array}{l}\text { R: Why do you think that the mass will be } 20 \mathrm{~g} \text { if } 1 \mathrm{~g} \text { table salt is dissolved in } 20 \mathrm{~g} \text { water? } \\
\text { S: Well, because the salt has been dissolved in the water and it cannot be seen. (HS-I-high achievers) } \\
\text { S: The salt mass is not considered because salt disappears after the mixing (HS-I-high achievers) }\end{array}$ \\
\hline $\begin{array}{l}\text { M13 } \\
\text { and } \\
\text { M14 }\end{array}$ & $\begin{array}{l}\text { R: What will happen to the mass of the system after the precipitate is formed? } \\
\text { S: I think it will be larger because the precipitate is not soluble and it stays at the bottom of the con- } \\
\text { tainer. (HS-I-low achievers) }\end{array}$ \\
\hline M15 & $\begin{array}{l}\text { R: You answered that the mass of the nail is the same after the rusting. Could you explain in more } \\
\text { details? } \\
\text { S: It means that there are exceptions of the law of conservation of matter. (HS-I-high achievers) }\end{array}$ \\
\hline M16 & $\begin{array}{l}\text { R: In this question considering the nail rusting you have answered that the mass would be the same. } \\
\text { Please explain. } \\
\text { S: Yes, the rust appears above the metal. } \\
\text { R: What do you mean? Does it "float" in the air? Is it necessary the nail to react with something to } \\
\text { become rusty? } \\
\text { S: Well, with oxygen. } \\
\text { R: Will the mass be the same after the reaction with oxygen? } \\
\text { S: Yes. (HS-I-high achievers) }\end{array}$ \\
\hline
\end{tabular}




\begin{tabular}{ll}
\hline $\begin{array}{l}\text { Miscon- } \\
\text { ception }\end{array}$ & Excerpt \\
\hline M17 & $/$ \\
\hline
\end{tabular}

R: You answered that the mass of the exhausted gasses from burning gasoline will weigh less than

M18, the mass of the petrol. Please explain your answer.

M19 S: It is so because the gasoline has been spent.

and $\quad$ R: OK, the petrol is consumed, but I am interested in the mass of the exhausted gasses.

M20 S: Their mass will be smaller because when they are exhausted in the air they become lighter than the gasoline. (HS-I-high achievers)

R: Why do you think that, after finishing all the changes, the mass of the test-tube will be smaller
than the initial one?
S: Well, because the mass of the phosphorus has been decreased.
R: Please, explain what you mean.
S: It came to ... some part of the phosphorus passed into the gaseous state because the smoke can be
observed.
R: And that is why you think that the overall mass will be smaller at the end?
S: That's right. (HS-I-high achievers)
S: Burning (combustion) is a physical change, physical form is changing; and chemical change ...
something in the chemical composition. For example, the explosion is a physical change.
R: What kind of change is burning of alcohol?
S: Physical one.
R: What is changing here?
S: The alcohol evaporates. While burning, carbon dioxide is being released.
R: Is it possible for alcohol to evaporate if I just pour it on the table, but not burn it?
S: No, it won't evaporate. (HS-IV-low achievers)
An ice cube ... when exposed to sunlight and heat, starts to melt and its particles broaden. (SS-VIII-
low achievers)

Here are some comments given by the students regarding these issues:

"S: Since molecular space is changing; their size must change, too." (HS-III-high achievers).

"R: You said that freezing will make the water molecule larger. Could you explain what did you mean?

S: Well ... the volume of ice ... water in the solid state is larger.

R: Do you think that if the volume is larger, the molecule must be larger, too?

S: That's right." (HS-II-low achievers)".

Several more categories of erroneous notions were registered when interviewing students although, fortunately, those were not widespread. Some of them are given below:

"Molecules that evaporate are lighter and go upward and the ones that stay in the vessel are heavier." (HS-III-low achievers);

"[When water evaporates] a vapor is formed and water molecules are decomposed into hydrogen and oxygen molecules." (HS-III-low achievers; HS-I-high achievers).

It was remarkable that many students disregard the particle conservation when describing changes. Thus, they said: "Part of the water disappears be- cause the water itself passes into the vapour." (HS-Ihigh achievers). Similar findings like those mentioned above are reported in the literature [63-66].

At the end of the interviewing process, students were asked whether the particles (atoms, molecules or ions) possess similar properties as the parent material. Some improvements in thinking regarding their earlier standpoints were noticeable, but still, many of them thought that the particles possess the same properties as the materials composed of them. They pictured the particles as miniversions of the substances they comprise. Some excerpts are given as a confirmation of the previously mentioned statements:

"It is my opinion ... that this statement is true. It is said in chemistry textbooks ... that the atom is the smallest particle that possesses the same physical and chemical properties as the substance it originates from." (HS-III-high achievers)

"Well ... because we are dealing with one substance, I think that the atoms will have the same physical and chemical properties ... because substances are made up of particles." (SS-VIII-high achievers);

"Atoms and all the other particles of which the substances are composed do not have the same 
properties as compounds have, because ... properties of that particular element or compound are added to the atoms." (SS-VIII-high achievers).

The excerpts regarding M1 and M2 in Table 2 clearly point out to the vagueness of the ideas of students and their inability to properly use the macroscopic and sub-microscopic concepts and the corresponding terminology. No differentiation is made between atoms and molecules, and between molecules (particles) and substances. Surely, a substance can not react with only one or a few particles.

Sometimes erroneous notions are not immediately perceptible and can be discovered only when looking at the in-depth responses. The next dialog is representative of that and it refers to the discussion of crystalline hydrates:

"R: What is your opinion? You have answered that copper(II) sulphate crystallizes as pentahydrate from water solutions. Why do you think this is the correct answer?

S: Last year we learned that ... er ... copper sulphate has five water molecules.

R: Where? Five water molecules in ...?

S: In its structure." (SS-VIII-high achievers).

In some textbooks [51] present are definitions of crystalline hydrates that use both macroscopic and sub-microscopic viewpoints. These can have harmful consequences to students and make difficult the discrimination between substances and their building blocks (particles), especially if such definitions are encountered in the early stages of the chemistry teaching.

In two of our previous papers $[32,43]$ we pointed out that it is likely that some erroneous concepts may originate because of imprecise definitions present in some physics textbooks [67]. It is more than obvious that some adjustments need to be done in clarifying similar concepts present in the teaching of chemistry and physics.

Another, very "popular" misconception among students was the one that all substances are built of molecules. Mostly, examples using sodium chloride were given. Many of the students had difficulties in recognizing ionic substances and had problems in defining their entities. Actually, many students thought that molecules are present in solid sodium chloride and that ions are formed only when it is dissolved. They related the sodium chloride formula to the term "molecule" simply because the symbols $\mathrm{Na}$ and $\mathrm{Cl}$ were written together. Similar findings were reported in the literature $[6,26,63]$.

The following excerpts are representative of the erroneous belief of students that entities in ionic substances resemble covalent ones.
"When it is not dissolved, molecules are present. In an aqueous solution ions are formed." (HSIII-low achievers).

"R: Are the $\mathrm{NaCl}$ entities in the solid substance molecules, ions or both?

\section{S: Molecules.}

R: Why do you think so?

S: There are no ionic properties when a substance is not in aqueous solution. When it is not dissolved it does not act as an ion." (HS-III-middle achievers).

This clearly shows that there is a schoolmade misconception among students concerning the building particles in ionic substances, expressing it on the sodium chloride example. One possible reason for such a wrong concept can be found in some textbooks [52] where the structural formulae of ionic compounds are represented in the same way as those of the covalent ones, giving examples using calotte models for every entity of every substance, including the ionic ones. In this way, a distorted picture in the minds of the students is created that can lasts for a very long time.

Many misconceptions about the law of conservation of matter were noticed among highschool students. Thus, students believed that when something is burned it is used up and nothing remains (M20) or when nails get rusty they lose weight (M16). A student even claimed that "gasoline transforms into light, heat and energy" (HS-Ihigh achievers).

During the discussion it was observed that some students did not make any difference between mass and density, so they gave statements such as: "A precipitate occurs when there is a mass difference, for example you can see precipitate in a cup of coffee" (HS-I-low achievers).

The findings briefly outlined above indicate that many misconceptions were present among students, some originating (erroneously) from the observations of the macroscopic properties of substances and transferring these properties in the submicroscopic world.

In our study, we found out that a large portion of students held the belief that the molecules themselves have the properties of the bulk matter. Furthermore, the data analysis from the tests and interviews clearly showed that students had certain difficulties in: a) recognizing symbolic representations (e.g. confusing symbols for atoms and formulae for molecules); b) making distinction between ionic and covalent substances and their particles and c) the ability to distinguish substances from molecules (i.e. differentiate concepts at macroscopic and sub-microscopic level). 
In conclusion, it is our firm belief that it must be categorically stated (by teachers, educators and researchers) that neither the substances are molecules nor molecules are substances. This statement should be strengthened by usage of visualization techniques (models, animations or computer software) as a required tool in teaching abstract concepts $[68,69]$ and their appropriate implementation in chemistry teaching.

Within the educational system in the Republic of Macedonia many obstacles exist (including financial, experimental, personal preferences and, especially, the teaching time available to the teachers) which could slow down the implementation of many intervention programs aimed to eliminate misconceptions and replace them with scientifically correct and acceptable knowledge.

\section{REFERENCES}

[1] C. Horton (with other members of the Modelling Instruction in High School Chemistry Action Research Teams at Arizona State University), Student Alternative Conceptions in Chemistry, 2007, retrieved from http://www.scribd.com/doc/ 52664 732/student-alternative-conceptions-in-chemistry (13 March 2014).

[2] Cambridge Dictionaries Online, 2012, Cambridge University Press, Cambridge. retrieved from http://dictionary.cambridge.org/dictionary/british/ misconception (13 March 2014).

[3] N. Canpolat, Turkish undergraduates' misconceptions of evaporation, evaporation rate, and vapour pressure. Int. J. Sci. Educ., 28 (2006), pp. 17571770.

[4] A. Pabuçcu, Ö. Geban, Remediating misconceptions concerning chemical bonding through conceptual change text, Hacet. Unit. Egit. Fak., 30 (2006), pp. 184-192.

[5] I. Eilks, T. Witteck, V. Pietzner, The role and potential dangers of visualisation when learning about sub-microscopic explanations in chemistry education, Centre Educ. Policy Stud. J., 2 (2012), pp. 125-145.

[6] R. Tasker, The VisChem project: Molecular level animations in chemistry - Potential and caution, UniServe Sci. News, 9 (1998), pp. 12-16.

[7] V. Garkov, Problems of the general chemistry course and possible solutions: the 1-2-1 general/organic/general curriculum and its challenges, Chemistry Bulg. J. Sci. Educ., 15 (2006), pp. 86-100.

[8] F. Lawrenz, Misconceptions of Physical Science Concepts among Elementary School Teachers, Sch. Sci. Math., 86 (1986), pp. 654-660.

[9] H. K. Boo, Teacher's misconceptions of Biological Science Concepts as Revealed in Science Ex- amination Papers, in: AARE International Education Research Conference (code BOO05099), Jeffery PL (Ed), 2005.

[10] H. D. Barke, A. Hazari, S. Yitbarek, Misconceptions in Chemistry. Addressing Perceptions in Chemical Education, Springer-Verlag, Berlin, 2009.

[11] A. H. Johnstone, Teaching of chemistry - Logical or psycho-logical?, Chem. Educ. Res. Pract., 1 (2000), pp. 9-15.

[12] B. Bucat, Pedagogical content knowledge as a way forward: Applied research in chemistry education. Chem. Educ. Res. Pract., 5 (2004), pp. 215-228.

[13] A. L. Chandrasegaran, D. F. Treagust, M. Mocerino, The development of a two-tier multiplechoice diagnostic instrument for evaluating secondary school students' ability to describe and explain chemical reactions using multiple levels of representation, Chem. Educ. Res. Pract., 8 (2007), pp. 293-307.

[14] M. R. Meijer, Macro-meso-micro thinking with structure-property relations for chemistry education. An explorative design-based study, Dissertation, Utrecht University (2011).

[15] N. Ben-Zvi, R. Gai, Macro- and micro-chemical comprehension of real-world phenomena, $J$. Chem. Educ., 71 (1994), pp. 730-732.

[16] D. F. Treagust, A. L. Chandrasesaran, A. N. M. Zain, E. T. Ong, M. Karpudewan, L. Halim, Evaluation of an intervention instructional program to facilitate understanding of basic particle concepts among students enrolled in several levels of study, Chem. Educ. Res. Pract., 12 (2011), pp. 251-261.

[17] G. Sirhan, Learning difficulties in chemistry: An overview, J. Turkish. Sci. Educ., 4 (2007), pp. 2-20.

[18] P. G. Nelson, Basic chemical concepts, Chem. Educ. Res. Pract., 4 (2003), pp. 19-24.

[19] H. S. Dhindsa, D. S. Treagust, Conceptual understanding of Bruneian tertiary students: Chemical bonding and structure, Brunei Int. J. Sci. Math. Educ., 1 (2009), pp. 33-51.

[20] II. Salame, S. Sarowar, S. Begum, D. Krauss, Students' alternative conceptions about atomic properties and the periodic table, Chem. Educator, 16 (2011), pp. 190-194.

[21] V. Kind, Beyond Appearances: Students' Misconceptions about Basic Chemical Ideas ( $2^{\text {nd }}$ edition), Durham University, Durham, 2004.

[22] M-H. Chiu, A national survey of students' conceptions in chemistry in Taiwan, Int. J. Sci. Educ., 29 (2005), pp. 421-452.

[23] W. H. Cliff, Chemistry misconceptions associated with under-standing calcium and phosphate homeostasis, Adv. Physiol. Educ., 33 (2009), pp. 323-328.

[24] M. Çalýk, A. Ayas, J.V. Ebenezer, A review of solution chemistry studies: Insights into students' 
conceptions. J. Sci. Educ. Technol., 14 (2005), pp. 29-50.

[25] İ. A. Kariper, An investigation into the misconceptions, erroneous ideas and limited conception of the $\mathrm{pH}$ concept in pre-service science teacher education, Chem. Educ. J. 14(1) (2011), Article 6 http://chem.sci.utsunomiya-u.ac.jp/v14n1/3Kaliper/kaliper.html (13 March 2014).

[26] T. Levy Nahum, A. Hofstein, R. MamlokNaaman, Z. Bar-Dov, Can final examinations amplify students' misconceptions in chemistry?, Chem. Educ. Res. Pract., 5 (2004), pp. 301-325.

[27] İ. Morgil, N. Yörük, Cross-age study of understanding of some concepts in chemistry subjects in science curriculum, J. Turkish. Sci. Educ., 3 (2006), pp. 15-27.

[28] K. S. Taber, Models, molecules and misconceptions: A commentary on "Secondary school students' misconceptions of covalent bonding", $J$. Turkish Sci. Educ., 8 (2011), pp. 3-18.

[29] C. J. Wenning, Dealing more effectively with alternative conceptions in science, $J$. Phys. Teacher Educ. Online, 5 (2008), pp. 11-19.

[30] B. M. Naah, M. J. Sanger, Student misconceptions in writing balanced equations for dissolving ionic compounds in water, Chem. Educ. Res. Pract., 13 (2012), pp. 186-194.

[31] M. B. Nakhleh, Why some students don't learn chemistry, J. Chem. Educ., 69 (1992), pp. 191-196.

[32] M. I. Stojanovska, V. M. Petruševski, B. T. Šoptrajanov, Addressing students' misconceptions concerning chemical reactions and symbolic representations, Chemistry: Bulg. J. Sci. Educ., 21 (2012), pp. 829-852.

[33] A. Badrian, T. Abdinejad, A. Naseriazar, A crossage study of Iranian students' various conceptions about the particulate nature of matter, J. Turkish Sci. Educ., 8 (2011), pp. 49-63.

[34] A. Banda, F. Mumba, V. M. Chabalengula, S. Mbewe, Teachers' understanding of the particulate nature of matter: The case of Zambian preservice science teachers, Asia-Pac. Forum Sci. Learn. Teach., 12 (2011), Article 4.

[35] J. A. Bindernagel, I. Eilks, Evaluating roadmaps to portray and develop chemistry teachers' PCK about curricular structures concerning sub-microscopic models, Chem. Educ. Res. Pract., 10 (2009), pp. 77-85.

[36] W. De Vos, A. H. Verdonk, The particulate nature of matter in science education and in science, $J$. Res. Sci. Teach., 33 (1996), pp. 657-664.

[37] C.A. Bridle, E.J. Yezierski, Evidence for the effectiveness of inquiry-based, particulate-level instruction on conceptions of the particulate nature of matter, J. Chem. Educ., 89 (2011), pp. 192-198.

[38] D. L. Gabel, K. V. Samuel, Understanding the particulate nature of matter, J. Chem. Educ., 64 (1987), pp. 695-697.
[39] H. Margel, B. S. Eylon, Z. Scherz, "We actually saw atoms with our own eyes" conceptions and convictions in using the scanning tunnelling microscope in junior high school, J. Chem. Educ., 81 (2004), pp. 558-566.

[40] H. Özmen, O. Kenan, Determination of the Turkish primary students' views about the particulate nature of matter, Asia-Pac. Forum Sci. Learn. Teach., 8 (2007), Article 1.

[41] K. Skamp, Atoms and molecules in primary science: What are teachers to do?, Aust. J. Edu. Chem., 69 (2009), pp. 5-10.

[42] E. J. Yezierski, J. P. Birk, Misconceptions about the particulate nature of matter. Using animations to close the gender gap, J. Chem. Educ., 83 (2006), pp. 954-960.

[43] M. I. Stojanovska, B. T. Šoptrajanov, V. M. Petruševski, Addressing misconceptions about the particulate nature of matter among secondaryschool and high-school students in the Republic of Macedonia, Creative Educ., 3 (2012), pp. 619-631.

[44] A. H. Haidar, Prospective Chemistry Teachers' Conceptions of the Conservation of Matter and Related Concepts, J. Res. Sci. Teach., 34 (2) (1997), pp. 181-197.

[45] H. Özmen, A. Ayas, Students' Difficulties in Understanding of the Conservation of Matter in Open and Closed-System Chemical Reactions, Chem. Educ. Res. Pract., 4 (2003), pp. 279-290.

[46] O. Lee, D. C. Eichinger, C. W. Anderson, G. D. Berkheimer, T. D. Blakeslee, Changing middle school students' conceptions of matter and molecules, J. Res. Sci. Teach., 30 (1993), pp. 249-270.

[47] R. Driver, A. Squires, P. Rushworth, V. WoodRobinson, Making Sense of Secondary Science: Research Into Children's Ideas, Routledge, London, 1994.

[48] G. Demircioğlu, Comparison of the effect of conceptual change texts implemented after and before instruction on secondary school students' understanding of acid-base concepts, Asia-Pac. Forum Sci. Learn. Teach., 10(2) (2009), Article 5.

[49] B. Šoptrajanov, Chemistry for the $1^{\text {st }}$ Year of Reformed Gymnasium Education, Prosvetno Delo, Skopje, 2002 (in Macedonian).

[50] S. Aleksovska, K. Stojanovski, Chemistry for the $4^{\text {th }}$ year of Reformed Gymnasium Education, Prosvetno delo, Skopje, 2005 (in Macedonian).

[51] S. Aleksovska, L. Antonovska, Chemistry for the $7^{\text {th }}$ grade of Eighth-year Secondary Education, Ministry of Education and Science of Republic of Macedonia, Skopje, 2010 (in Macedonian).

[52] S. Cvetković, Chemistry for the $1^{\text {st }}$ Year of Reformed Gymnasium Education, Prosvetno Delo, Skopje, 2002 (in Macedonian).

[53] A. Hussein, The use of triangulation in social sciences research: Can qualitative and quantitative methods be combined?, J. Comp. Soc. Work., 1 (2009), pp. 1-12. 
[54] T. D. Jick, Mixing qualitative and quantitative methods: Triangulation in action, Admin. Sci. Quart., 24 (1979), pp. 602-611.

[55] P. Singh, The unexpected reward of qualitative research in assessment: A case example, Qualit. Report., 13 (2008), pp. 278-300.

[56] M. Sözbilir, T. Pınarbaşı, N. Canpolat, Prospective chemistry teachers' conceptions of chemical thermodynamics and kinetics, Eurasia J. Math. Sci. \& T., 6 (2010), pp. 111-121.

[57] H. Eybe, H. Schmidt, Group discussions as a tool for investigating students' concepts, Chem. Educ. Res. Pract., 5 (2004), pp. 265-280.

[58] H. Muzaffar, D. M. Castelli, D. Goss, J. A. Scherer, K. Chapman-Novakofski, Middle school students want more than games for health education on the internet, Creat. Educ., 2 (2011), pp. 393-397.

[59] S. Nair, T. K. Ngang, Exploring parent's and teacher's views of primary pupils' thinking skills and problem solving skills, Creat. Educ., 3 (2012), pp. 30-36.

[60] J. Osborne, S. Collins, Pupils' views of the role and value of the science curriculum: A focus group study, Int. J. Sci. Educ., 23 (2001), pp. 441-467.

[61] A. Carovska, Study of the notions related to the law of conservation of matter in $1^{\text {st }}$ year high-school students, Diploma work, Ss Cyril and Methodius University of Skopje (2013) (In Macedonian).

[62] M. Milenković, Inspection of first year students' understanding regarding the law of conservation of matter, Diploma work, Ss. Cyril and Methodius University of Skopje (2012) (In Macedonian).

[63] K. Taber, Building the structural concepts of chemistry: Some considerations from educational research, Chem. Educ. Res. Pract., 2 (2001), pp. 123-158.

[64] E. Tatar, Prospective primary school teachers' misconceptions about states of matter, Educ. Res. Rev., 6 (2011), pp. 197-200.

[65] K. Mayer, Addressing students' misconceptions about gases, mass, and composition, J. Chem. Educ., 88 (2011), pp. 111-115.

[66] A. Regan, P. Childs, S. Hayes, The use of an intervention programme to improve undergraduate students' chemical knowledge and address their misconceptions, Chem. Educ. Res. Pract., 12 (2011), pp. 219-227.

[67] S. Gešoski, F. Nonkulovski, Physics for the $7^{\text {th }}$ Grade of Eighth-Year-Secondary Education, Ministry of Education and Science of Republic of Macedonia, Skopje, 2009 (in Macedonian).

[68] T. J. José, V. M. Williamson, Molecular visualization in science education: An evaluation of an NSF-sponsored workshop, J. Chem. Educ., 82 (2005), pp. 937-943.

[69] R. W. Milne, Animating reactions. A low-cost activity for particle conceptualization at the secondary level, J. Chem. Educ., 76 (1999), pp. 50-51.

\title{
ИСТРАЖУВАЊЕ ЗА КОРИСТЕЊЕТО НА ТРИТЕ НИВОА НА РАЗМИСЛУВАЊЕ И ПРЕТСТАВУВАњЕ
}

\author{
Марина Стојановска ${ }^{1 *}$, Владимир М. Петрушевски ${ }^{1}$, Бојан Шоптрајанов² \\ ${ }^{1}$ Институт за хемија, Природно-математички факултет, \\ Универзитет „Св. Кирил и Методиј“, Скопје, Република Македонија \\ ${ }^{2}$ Македонска академија на науките и уметностите, Скопје, Република Македонија
}

Во трудот се претставени резултатите од истражување посветено на евентуалното присуство на погрешни претстави (мисконцепции) коишто се во врска со трите нивоа на претставување, односно разбирање (макроскопското, суб-микроскопското и симболичното).

Инаку, мисконцепциите можат да бидат формирани претходно, пред формално да започне процесот на поучување ( $\bar{u} р е \bar{u} к о н ц е \bar{u} \bar{u} u)$, но може да потекнуваат и од самиот наставен процес (училишни мискониейции). Многу училишни мисконцепции се должат на фактот што учениците не прават разлика меѓу трите нивоа на размислување. Мисконцепциите што се резултат на мешање на овие три нивоа во хемијата се многу распространети и тешко се искоренуваат.

Во нашето истражување е направена анализа на точните и погрешните одговори на учениците на тестовите. Дадена е листа на мисконцепции што се забележани во одговорите на прашањата од тестовниот материјал кај испитуваните ученици, како и извадоци од спроведените интервјуа како доказ за размислувањата на учениците. интервјуа

Клучни зборови: три нивоа на размислување/претставување; мисконцепции; настава по хемија; 